\title{
Transcriptional insights into sugarcane aquaporin genes under water deficit conditions
}

DEVENDRA KUMAR ( $\nabla$ dkmadhur@gmail.com )

Mangalayatan University https://orcid.org/0000-0001-9516-4830

\section{Research Article}

Keywords: Aquaporins, Water stress, Antioxidant activity, PIPs, Formative growth stage

Posted Date: July 7th, 2021

DOl: https://doi.org/10.21203/rs.3.rs-185344/v2

License: (c) (i) This work is licensed under a Creative Commons Attribution 4.0 International License. Read Full License 


\section{Abstract}

Water deficit in soil during formative growth stage adversely hinders the crop productivity. Plant develop a key chain of mechanisms to cope these strains. Characterization of genotypes under water deficit will provide the basis for breeding new germplasm for efficient utilization of water and nutrients and adaptation to water stress. To achieve this, two tolerant (Co 98014 and Co 0118) and two sensitive (CoJ 85 and Co 89003) sugarcane genotypes were assessed for antioxidant responses followed by differential expression of three aquaporin genes (ShPIP2-1, ShPIP-5 and ShPIP2-6) under two water deficit conditions. The MDA and $\mathrm{H}_{2} \mathrm{O}_{2}$ contents were significantly higher $(p<0.05)$ in sensitive genotypes as compared to tolerant ones, whereas SOD activity was higher $(p<0.05)$ in tolerant than sensitive genotypes. The transcript analysis of AQPs reveals upregulation of ShPIP2;5, whereas down-regulation of ShPIP2;1 and ShPIP2;6 when plants were imposed to water deficit conditions. The findings under study suggested the role of PIP2 AQPs in regulation of plant water status under water deficit conditions.

\section{Key Message}

Substantial alterations in aquaporin (PIP2) gene transcripts as well as higher antioxidant activity of tolerant genotypes witnessed the role of AQPs in sustaining plant water status during stress conditions.

\section{Introduction}

Sugarcane (Saccharum officinarum L.), an economically important and the largest area occupying Indian crop suffers due to various biotic and abiotic constraints. Among various abiotic constraints, drought or water deficit is the most drastic factor in regions suffering with water scarcity, that adversely affects this crop from initial growth to development phases [1]. Production of sugarcane is worsening with the rapid expansion of drought affected areas of the world. As a major part of sugarcane growing area in India is directly affected by drought that alters plant functioning at very early stages. Sugarcane production can still be improved further if we can put a check on a major agricultural problem i.e. water stress. Thus, the varieties having tolerance towards drought is prior need to sustain sugarcane productivity during this changing climate scenario.

Drought stress is known to decreased chlorophyll and relative water contents, water potential and affects other various metabolic and physiological processes [1]. Water deficit induce reactive oxygen species (ROS) accumulation and lipid peroxidation in plants that could have an effect on membrane lipids, proteins and nucleic acids, resulting in increased membrane leakage of solutes under drought stress [2]. Thus, cellular damage is caused in plants due to oxidative stress [3]. To reduce such stress, plants have developed a complex multitude of antioxidant defense systems to limit ROS and maintain redox homeostasis such as superoxide dismutase, catalase and peroxidase etc [1].

In apart to the physio-biochemical changes, a coordinated set of signalling networks are involved to control stress consequences by regulating numerous of genes that encode protein for plant survival [4]. 
The genes having role in stress acclimation encode for chaperones (HSPs), aquaporins (water channel proteins), proteases, detoxifying enzymes and free radical scavengers. Aquaporins (AQPs) are water facilitating proteins that transport water, gases $\left(\mathrm{NH}_{3}\right.$ and $\mathrm{CO}_{2}$ ) and small solutes (urea, $\mathrm{H}_{3} \mathrm{BO}_{4}$ and $\mathrm{H}_{4} \mathrm{SiO}_{4}$ ) through the membrane [5]. Importance of AQPs in water transport suggest role of these proteins in various physiological responses to abiotic stresses like drought [6]. Amino acid identity of plant AQPs classify aquaporins into five subfamilies: plasma membrane intrinsic protein (PIPs), tonoplast intrinsic proteins (TIPs), nodulin 26-like proteins (NIPs), small basic intrinsic proteins (SIPs) and X intrinsic proteins (XIPs) [7]. Phylogenetic study based on nucleotides sequence revealed 33 isoforms of AQPs consisting four subfamilies i.e. 13 PIPs, 11 TIPs, 6 NIPs and 3 SIPs. The subfamily PIP can be further subdivided into PIP1 and PIP2, consists five and eight proteins, respectively. The transcript study of three PIPs (ShPIP2;1, ShPIP2;5 and ShPIP2;6) evaluated in two sugarcane genotypes (IACSP94-2094 and IACSP97-7065) under water deficit through qPCR showed these isoforms were responsive to drought and their expression pattern were dependent of genotype, experimental conditions [8]. The isoform PIP2 exhibit more efficient water channel activity than PIP1 [9]. The abundance of PIP2 transcripts has been established by qPCR studies suggest their presence in different tissues and organs under water stress conditions [8].

Drought tolerance in sugarcane is not same in all species, besides in certain species, mechanisms can operate concomitantly producing tolerance through their amalgamated effects. No particular studies of tolerance mechanisms in response to water stress has been done in the sugarcane genotypes of semiarid region of India. Even the type of tolerance mechanism for drought tolerance are not fully understood. Thereby, breeding for drought tolerance in sugarcane require a depth understanding of divergent resistance mechanisms. Molecular techniques, particularly gene expression profiles has been proved as a reliable tool to identify transcript involved in drought tolerance [10]. Therefore, present study was designed on evaluation of sugarcane genotypes of semi-arid region of India through antioxidant activity and differential expression pattern analysis of aquaporin genes under different water deficit conditions.

\section{Materials And Methods}

\section{Plant materials and experimental conditions}

Two tolerant (Co 98014, Co 0118), and two sensitive (CoJ 85, Co 89003) sugarcane genotypes of semiarid region of India that have contradictory response to water stress as per their physio-biochemical and antioxidant activities [1] were chosen under this study. Experimental trial was conducted under rain out shelter, field laboratory, Department of Biotechnology, Sardar Vallabhbhai Patel University of Agriculture and Technology, Meerut, U.P., India and qRT-PCR for AQPs genes was performed at DUVASU, Mathura, India. Each genotype was planted in plastic pots $\left(39 \times 33 \mathrm{~cm}^{2}\right)$ containing $25.0 \mathrm{~kg}$ of soil and $5.0 \mathrm{~kg}$ farm yard manure (FYM) in completely randomized design. Healthy and infection free sugarcane setts (2 budded) were prepared and treated prior to planting with 0.2 percent mixture of mancozeb + carbendazim for $10 \mathrm{~min}$ followed by chlorpyrifos $20 \mathrm{EC}$ for $5 \mathrm{~min}$. The soil pH, electrical conductivity and organic carbon were 7.2, $1.3 \mathrm{dSm}^{-1}$ and $4.3 \mathrm{~g} / \mathrm{kg}$. Particle size distribution (\%) was 58 (sand), 25 (silt) and 22 
(clay). Three setts (2 budded) were planted in each pot with three replications for each genotype. After 60 days of planting, thinning was done by leaving only three plants in each pot. Moisture of soil contents was determined as per gravimetric method. Soil moisture content ( $0-20 \mathrm{~cm}$ soil depth) obtained was $23.9 \%$ at the time of sowing and it was $18.1 \%, 5.9 \%$ on $135^{\text {th }}$ and $150^{\text {th }}$ day, respectively. The similar management inputs like fertilizer and insecticides for proper growth and disease control were provided. On $120^{\text {th }}$ day, samples were collected and marked as control, after that plants were imposed to water withholding. Next samplings were done on $135^{\text {th }}$ and $150^{\text {th }}$ day after imposing water deficit. The third expanded leaf from top was collected as sample in aseptic manner in each case by minimizing activity of ribonucleases at 09:00 h, frozen in $\mathrm{LN}_{2}$ and immediately stored at $-80^{\circ} \mathrm{C}$. Samples were collected in two replications from each pot, one for analysis of antioxidant activity and another one for AQPs expression.

\section{Antioxidant analysis}

Malondialdehyde (MDA) assay was done by the measuring thio-barbituric acid reactive substance and expressed as $\mu \mathrm{M} \mathrm{MDA} / \mathrm{g}$ FW using extinction coefficient of $155 \mathrm{mM}^{-1} \mathrm{~cm}^{-1}$ [11]. $\mathrm{H}_{2} \mathrm{O}_{2}$ content was measured by the peroxidase coupled assay [12]. Superoxide dismutase (SOD) measurement was performed by nitroblue tetrazolium (NBT) method and expressed as units/mg protein [13].

\section{RNA extraction and cDNA synthesis}

Total RNA was isolated using TRIZOL reagent (Invitrogen, USA) with some modifications. The $200 \mathrm{mg}$ of leaf sample was crushed in $\mathrm{LN}_{2}$ and $1.5 \mathrm{ml}$ of TRIZOL was added and transferred to RNase free tube. Then, $30 \mu \mathrm{l} \beta$-mercaptoethanol (BME) and $40 \mu$ lithiothreitol (DTT) was added and mixed vigorously by pipetting by passing several times through tip of pipette. Samples were incubated for $5 \mathrm{~min}$ at room temp by adding chloroform $(300 \mu \mathrm{l})$ and centrifuged $\left(12000 \mathrm{~g}, 15 \mathrm{~min}\right.$ at $\left.4{ }^{\circ} \mathrm{C}\right)$. Upper aqueous phase was separated carefully without disturbing interphase and precipitated by adding chilled isopropanol ( $250 \mu \mathrm{l})$, $1.5 \mathrm{M} \mathrm{NaCl}(125 \mu \mathrm{l}), 0.8 \mathrm{M}$ potassium acetate $(125 \mu \mathrm{l})$ and incubated for $10 \mathrm{~min}$. The samples were centrifuged $\left(12000 \mathrm{~g}, 10 \mathrm{~min}, 4^{\circ} \mathrm{C}\right)$ and supernatant was decanted. RNA pellet was washed twice with 1 $\mathrm{ml}$ of $75 \%$ ethanol and pellet was air dried and dissolved in $75 \mu \mathrm{l}$ nuclease free water (NFW). Residual genomic DNA contamination was removed using DNase I (GeNei, Bangalore) as per the manufacturer instructions. The concentration of RNA was determined using Biophotometer (Eppendorf, Germany). The integrity of RNA was analyzed using $0.08 \%$ agarose gel electrophoresis. A total of 36 samples of RNA were isolated and reverse transcribed to cDNA in a final volume of $20 \mu \mathrm{l}$ using m-mulv RT-PCR kit (GeNei, Bangalore) by taking $1 \mu \mathrm{l}$ oligo dT, $1 \mu \mathrm{l}$ random Hexamer primers and $2 \mu \mathrm{g}$ of total RNA. The volume was finalized to $12 \mu \mathrm{l}$ by NFW and incubated at $65^{\circ} \mathrm{C}$ for $10 \mathrm{~min}$. The tubes were ice chilled and master mix was prepared by taking $10 \mu \mathrm{l}$ of $5 \mathrm{X}$ reaction buffer, $1 \mu \mathrm{l}$ m-mulv RT, $0.5 \mu$ l each dNTPs and $1 \mu \mathrm{l}$ RNase inhibitor. To minimize pipetting error, the master mix was prepared in one PCR tube $(0.2 \mathrm{ml})$ by taking multiple values of required reagents as per the number of samples and mixed. The $8 \mu$ l of master mix was mixed to each tube and incubated with $1 \mu \mathrm{l}$ oligo dT and $1 \mu \mathrm{l}$ of random hexamer primers. Reaction was carried out in thermal cycler at $37^{\circ} \mathrm{C}$ for $1 \mathrm{~h}$ followed by $95^{\circ} \mathrm{C}$ for 5 minutes. The cDNA was stored at $-20^{\circ} \mathrm{C}$. 


\section{Primer sequences}

Primer for sugarcane AQPs used under study were taken from already published primer sequences [8]. These sequences were further aligned using PRIMER-BLAST at NCBI for specificity. $\beta$-tubulin [14] was amplified as internal reference gene (Table 1).

\section{Quantitative real-time PCR (qRT-PCR)}

The qRT-PCR was performed with Hi-SYBr Master Mix (MolBio-HIMEDIA) using CFX-96 real-time thermal cycler C-1000 (BIO-RAD) for gene expression in a final volume of $20 \mu \mathrm{l}$ containing $10 \mu \mathrm{l}$ of Hi-SYBr Mix (MolBio-HIMEDIA), $1 \mu$ l each forward and reverse primer and cDNA template ( $\leq 100 \mathrm{ng})$. A total of three biological samples with three technical replicates were used for each gene. The thermal profiles were set with an initial temp $95^{\circ} \mathrm{C}$ for 3 min followed by 36 cycles of PCR $\left(95^{\circ} \mathrm{C}\right.$ for $30 \mathrm{sec}, 56.5^{\circ} \mathrm{C}$ for ShPIP2; 1 , $51^{\circ} \mathrm{C}$ for ShPIP2;5, $57^{\circ} \mathrm{C}$ for ShPIP2; 6 and $58.5^{\circ} \mathrm{C}$ for b-tubulin for $30 \mathrm{sec}$ with plate read) and $72{ }^{\circ} \mathrm{C}$ for $30 \mathrm{sec}$. The melt curve was obtained between $65^{\circ} \mathrm{C}$ to $95^{\circ} \mathrm{C}$ with an increment of $0.5^{\circ} \mathrm{C}$ per $5 \mathrm{sec}$ and plate read. No template control (NTC) also included. For normalization, b-tubulin was taken as housekeeping gene. The differential expression was calculated by obtaining cycle threshold (Ct) value using the equation $2^{(-\Delta \Delta C t)}[15]$.

\section{Data analysis}

Data analysis was estimated using software SPSS (SPSS 20.0 for windows, Chicago, USA). Analysis of Variance (ANOVA) was performed following Tukey's-b multiple range test and significant difference was determined at probability level of $5 \%$.

\section{Results}

\section{Lipid peroxidation}

Thio-barbituric acid reactive substance (MDA content) underwent an increase under water deficit in case of all genotypes. However, the proportion of its contents was significantly more increased in Co 89003 (1.9 fold) and CoJ 85 (1.84 fold) than Co 98014 and Co 0118 (Table 2, Fig 1a). The tolerant cultivars not showed any significant $(p>0.05)$ upsurge in comparison to the irrigated condition but it was comparatively higher as the water deficit level increased (Table 2). There was no significant $(p>0.05)$ difference for fold changes in MDA content within tolerant genotypes in all treatment conditions.

\section{$\mathrm{H}_{2} \mathrm{O}_{2}$ content}

A significantly higher $(p<0.05) \mathrm{H}_{2} \mathrm{O}_{2}$ content was observed in sensitive genotypes (CoJ 85 and Co 89003) during both stress treatments whereas tolerant ones (Co 98014 and Co0118) didn't showed any remarkable changes (Table 2, Fig. $1 \mathrm{~b}$ ). The significant $(p<0.05)$ difference in $\mathrm{H}_{2} \mathrm{O}_{2}$ content was also 
shown within sensitive genotypes. The values for percent increase in $\mathrm{H}_{2} \mathrm{O}_{2}$ content was comparatively increased within genotypes as the water deficit time increased. However, a slight increase in $\mathrm{H}_{2} \mathrm{O}_{2}$ content was shown in Co 98014 on $150^{\text {th }}$ day but there was no significant $(p<0.05)$ change observed in Co 0118 .

\section{Superoxide dismutase (SOD)}

During water deficit conditions, a dramatic increase in SOD activity was showed in tolerant genotypes as compared to sensitive ones. The genotype Co 98014 was shown with the highest and Co 89003 with the lowest SOD activity (Table 2, Fig 1c). The tolerant genotypes showed significantly higher $(p<0.05)$ upsurge in SOD activity on $135^{\text {th }}$ as well as on $150^{\text {th }}$ day in comparison to sensitive genotypes. Genotype CoJ 85 also showed significantly $(p<0.05)$ higher activity during water deficit conditions, but genotype Co 89003 didn't show any significant $(p>0.05)$ difference in SOD activity in any treatment condition.

\section{Expression pattern of AQPs}

The relative mRNA transcript of ShPIP2; 1 , ShPIP2; 5 and ShPIP2; 6 was increased under water deficit in all genotypes (Fig 2a-2c). ShPIP2;1 exhibited significant $(p<0.05)$ change under water deficit conditions in genotype Co 98014, Co 0118 and CoJ 85 whereas genotype Co 89003 didn't show any remarkable $(p>0.05)$ change in ShPIP2;1 transcript level. On $135^{\text {th }}$ day, the genotype Co 98014 exhibited a dramatic increase in ShPIP2; 1 transcript but it was decreased significantly on $150^{\text {th }}$ day as compared to control (120 $0^{\text {th }}$ day). The genotype Co 0118 showed significant decline in ShPIP2; 1 expression in both water deficit conditions. A significant reduction on $135^{\text {th }}$ day whereas significant upsurge on $150^{\text {th }}$ day in transcript abundance of ShPIP2; 1 was shown by genotype CoJ 85 when compared to $120^{\text {th }}$ day (Fig. 2a).

A significant increase in ShPIP2;5 transcript was observed in water deficit level-II ( $150^{\text {th }}$ day) in comparison to both normal ( $120^{\text {th }}$ day) and water deficit level-I ( $135^{\text {th }}$ day), however transcript level of ShPIP2; 5 was significantly higher on $150^{\text {th }}$ day also as compared to irrigated condition $\left(120^{\text {th }}\right.$ day) (Fig. 2b). The transcript level of ShPIP2;5 under water deficit was significantly higher in tolerant genotypes (Co 98014 and Co 0118) than sensitive ones (CoJ 85 and Co 89003). In genotype Co 89003, ShPIP;5 expression didn't show any remarkable changes on $150^{\text {th }}$ day however, genotype CoJ 85 was observed with significant difference in ShPIP2;5 transcript on $150^{\text {th }}$ day when compared with irrigated conditions $\left(120^{\text {th }}\right.$ day).

The ShPIP2;6 expression profile was observed significantly $(p>0.05)$ similar in tolerant genotypes, however Co 98014 showed similar expression on $120^{\text {th }}$ and $135^{\text {th }}$ day whereas, Co 0118 on $120^{\text {th }}$ and 150 day. The significant differences were shown in sensitive genotypes for ShPIP2;6 expression. A significant increase $(p<0.05)$ in ShPIP2; 6 expression was observed on $135^{\text {th }}$ day as compared to control in genotype Co 0118. However, it was significantly decreased in tolerant (Co 98014 and Co 0118) and 
increased in sensitive genotypes (CoJ 85 and Co 89003) on 150 th day. The sensitive genotypes showed significantly decreased ShPIP2;6 expression on $135^{\text {th }}$ day.

\section{Discussion}

Unfavorable circumstances like water deficit induce ROS production that causes oxidative injuries to plant cell. In response to oxidative stress, plant develop its antioxidant defense system to maintain cellular homeostasis [1, 2]. It is known that water deficit is detected early in roots, and subsequently its effects trigger modifications in leaves [16].

Malondialdehyde (MDA) is a by-product generated by cell under oxidative stress [17]. The oxidative degradation of lipids by ROS generated oxidative stress leads to lipid peroxidation and increase in $\mathrm{H}_{2} \mathrm{O}_{2}$ content. Increase in MDA and $\mathrm{H}_{2} \mathrm{O}_{2}$ content production is the indicator of oxidative damage [18]. This suggests a correlation between drought and oxidative stress. Under this study, malondialdehyde as well as $\mathrm{H}_{2} \mathrm{O}_{2}$ content of leaves increased for all the genotypes under water deficit conditions. However, sensitive genotypes (Co 89003 and $\mathrm{CoJ}$ 85) showed higher increase in MDA and $\mathrm{H}_{2} \mathrm{O}_{2}$ contents than tolerant genotypes (Co 98014 and Co 0118), indicating the oxidative stress under water deficit condition (Fig 1a-1b). Increased MDA content has also been seen in stressed sugarcane [19], wheat [20] and fababean [21] plants under drought stress conditions. The sugarcane plants under water stress accompanied high level of $\mathrm{H}_{2} \mathrm{O}_{2}$ content with the increase in lipid peroxidation [22]. Tolerant varieties of sugarcane showed $50.5 \%$ lesser lipid peroxidation as compared to susceptible varieties [23]. To scavenge and detoxify MDA content and $\mathrm{H}_{2} \mathrm{O}_{2}$ production at intracellular level, antioxidant enzymes are induced to protect the plants under drought stress conditions $[1,24]$. In present study, SOD was significantly increased under water deficit conditions (Fig 1C). The SOD activity was higher in tolerant genotypes than sensitive ones responding to water deficit stress. It indicated that the genotypes induced oxidative stress and their antioxidant enzymes caused to detoxify cells. The results under study are similar to previous reports in sugarcane [25].

Aquaporins are integral membrane proteins, present in all plant organs/tissues and participate in transfer of water and solutes. Plasma membrane integral proteins (PIPs) are highly influenced by environmental constraints like water deficit or drought [5]. Gene expression study had been successfully used to identify stress-induced genes in barley [26]. The response to water deficit is detected early in roots and leaves [16]. Drought stress affected the expression pattern of PIP2 proteins in plants leaves of rice [7, 27]. Difference in AQPs expression was also showed in tolerant and sensitive rice [28]. Expression pattern of PIP Aquaporins vary with the level of stress, species and isoform $[8,29]$. The AQPs expression pattern under study revealed upregulation of ShPIP2;5, and down-regulation of ShPIP2; 1 and ShPIP2;6 when plants were imposed to water deficit conditions (Fig. 2a-2c). Findings of study are in harmony with earlier researchers reports $[8,29,30]$. HT-SuperSAGE libraries analysis of two bulks under drought showed divergent AQPs expression in tolerant and sensitive sugarcane genotypes indicated AQPs expression is 
genotype specific [30]. Cultivars of same species also respond differently to drought as per their tolerance ability [6].

The study revealed wide variations in antioxidant activity of sugarcane genotypes. The higher upregulation of ShPIP2; 5 during both water deficit conditions, and more downregulation of ShPIP2;1 and ShPIP2; 6 in severe water deficit condition ( $150^{\text {th }}$ day) in tolerant genotypes as compared to sensitives discriminate their possible mechanism for plant to direct the water flux for specific tissues, organs or cells to reduce water loss under higher water deficit level as these proteins affects water transport. However, further protein profiling-based studies need to be employed to explore the role of these proteins.

\section{Conclusion}

The study discriminated wide variations in antioxidant responses. Differential expression pattern of AQPs reveals that PIP2 was responsive to water deficit conditions. The ShPIP2;5 upregulation suggested its role in maintenance of cell water status under water deficit as these proteins affects water transport. However, further protein profiling-based studies need to be employed in other crops to explore the role of these proteins.

\section{Abbreviations}

AQPs--aquaporins; PIPs--plasma membrane intrinsic proteins; ROS--reactive oxygen species; SOD-superoxide dismutase; MDA--malondialdehyde; $\mathrm{H}_{2} \mathrm{O}_{2}$-hydrogen peroxide; qRT-PCR--quantitative realtime PCR

\section{Declarations}

\section{ACKNOWLEDGEMENTS}

The authors extend their hearty gratitude to Dr. Brijesh Yadav, Assistant Professor, Department of Physiology, DUVASU Mathura for providing qRT-PCR facility to conduct this research work. Help received by Directorate of Research, SVPUA\&T, Meerut for conducting the field based research is duly acknowledged.

\section{Author contribution}

Conceptualization, D.K. and R.S.S.; Data curation, D.K.; Formal analysis and Investigation, D.K. and N.M.; Writing - original draft, D.K. All the authors has read and approved the manuscript.

\section{Funding}

No funds, grants, or other support was received to conduct this research work

\section{Conflicts of Interest}


The authors have no conflicts of interest to declare that are relevant to the content of this article.

\section{References}

1. Kumar, D., Malik, N., and Sengar, R.S., Physio-biochemical insights into sugarcane genotypes under water stress, Rhythm Res., 2021, vol. 52, no. 1, pp. 92-115. doi 10.1080/09291016.2019.1587838

2. Liu, C., Liu, Y., Guo, K., Fan, D., Li, G., Zheng, Y., Yu, L., and Yang, R., Effect of drought on pigments, osmotic adjustment and antioxidant enzymes in six woody plant species in karst habitats of Southwestern China, Exp. Bot., 2011, vol. 71, pp. 174--183.

3. Miller, G., Suzuki, N., Ciftci-Yilmaz, S., and Mittler, R., Reactive oxygen species homeostasis and signalling during drought and salinity stresses, Plant Cell Environ., 2010, vol. 33, pp. 453-467.

4. Chaves, M.M., Maroco, J.P., and Pereira, J.S., Understanding plant responses to drought-from genes to the whole plant, Functional Plant Biol., 2003, vol. 30, pp. 239-264.

5. Maurel, C., Verdoucq, L., Luu, D., and Santoni, V., Plant aquaporins: membrane channels with multiple integrated functions, Annual Rev. Plant Biol., 2008, vol. 59, pp. 595--624.

6. Heinen, R.B., Ye, Q., and Chaumont, F., Role of aquaporins in leaf physiology, Exp. Bot., 2009, vol. 60, pp. 2971-2985.

7. Sakurai, J., Ishikawa, F., Yamaguchi, T., Uemura, M., and Maeshima, M., Identification of 33 rice aquaporin genes and analysis of their expression and function, Plant Cell Physiol., 2005, vol. 46, pp. 1568-1577.

8. de-Andrade, L.M., Nobile, P.M., Ribeiro, R.V., de-Oliveira, J.F.N.C., Figueira, A.V.O., Frigel, L.T.M., Nunes, D., Perecin, D., Brito, M.S., Pires, R.C.M., Landell, M.G.A., and Creste, S., Characterization of PIP2 aquaporins in Saccharum hybrids, Plant Gene, 2016, pp. 31-37.

9. Kaldenhoff, R., and Fischer, M., Aquaporins in plants, Acta Physiol., 2006, vol. 187, pp. 169-176.

10. Rodrigues, F.A., de-Laia, M.L., and Zingaretti, S.M., Analysis of gene expression profiles under water stress in tolerant and sensitive sugarcane plants, Plant Sci., 2009, vol. 176, pp. 286--302.

11. Heath, R.L., and Packer, L., Photoperoxidation in isolated chloroplasts. I. Kinetics and stoichiometry of fatty acid peroxidation, Biochem. Biophys., 1968, vol. 125, pp. 189-198.

12. Veljovic-Jovanovic, S., Noctor, G., and Foyer, C.H., The potential influence of artefactual interference by tissue phenolics and ascorbate, Plant Physiol. Biochem., 2002, vol. 40, pp. 501-507.

13. Beyer, W.F., and Fridovich, I., Assaying for superoxide dismutase activity: some large consequences of minor changes in conditions, Analytical Biochem., 1987, vol. 161, pp. 559-66.

14. Andrade, J.C.F., Terto, J., Silva, J.V., and Almeida, C., Expression profiles of sugarcane under drought conditions: Variation in gene regulation, Mol. Biol., 2015, vol. 38, no. 4, pp. 465--469. doi $10.1590 /$ S1415-475738420140288

15. Livak, K.J., and Schmittgen, T.D., Analysis of relative gene expression data using realtime quantitative PCR and the $2^{\text {ddCT }}$ methods, Methods, 2001, vol. 25 pp. 402-408. 
16. Locy, R.D., Hasegawa, P.M., and Bressan, R.A., Stress physiology, Plant Physiology, Taiz, L., Zeiger, E., $3^{\text {rd }}$, Sinauer Associates, Inc. -Sunderland, 2002, pp. 2438-2442.

17. Huang, G.T., Ma, S.L., and Bai, L.P., Signal transduction during cold, salt, and drought stresses in plants, Biol. Reports, 2012, vol. 39 no. 2, pp. 969-987.

18. Abbas, S., Ahmad, S., Sabir, S. and Shah, A., Detection of drought tolerant sugarcane genotypes (Saccharum officinarum) using lipid peroxidation, antioxidant activity, glycine-betaine and proline contents, Soil Sci. Plant Nutr., 2014, vol. 14, pp. 233--243.

19. Pagariya, M.C., Harikrishnan, M., Kulkarni, P.A., Devarumath, R.M., and Kawar, P.G., Physiobiochemical analysis and transcript profiling of Saccharum officinarum submitted to salt stress, Acta Physiol. Plant., 2011, vol. 33, no. 4, pp. 1411-1424.

20. Sultan, M., Hui, L., Yang, L.J., and Xian, Z.H., Assessment of drought tolerance of some Triticum L. species through physiological indices, Czech J. Genet. Plant Breed., 2012, vol. 48, no. 4, pp. 178--184.

21. Siddiqui, M.H., Al-Khaishany, M.Y., Al-Qutami, M.A., Al-Whaibi, M.H., Grover, A., Ali, H.M., Al-Wahibi, M.S., and Bukhari, N.A., Response of different genotypes of faba bean plant to drought stress, J. Mol. Sci., 2015, vol. 16, pp. 10214-10227.

22. Boaretto, L.F., Carvalho, G., Borgo, L., Creste, S., Landell, M.G., Mazzafera, P., and Azevedo, R.A., Water stress reveals differential antioxidant responses of tolerant and nontolerant sugarcane genotypes, Plant Physiol. Biochem., 2014, vol. 74, pp. 165-175.

23. Manimekalai, R., Narayanan, J., Gokul, M., Selvi, A., Gomati, R., and Kumar, R.A., Biochemical and physiological response to oxidative stress in cultivated sugarcane and wild genera, J. Plant Physiol., 2018, vol. 23, no. 2, pp. 261-270.

24. Patade, V.P., Bhargava, S., and Suprasanna, P., Salt and drought tolerance of sugarcane under isoosmotic salt and water stress: growth, osmolytes accumulation, and antioxidant defense, Plant Interact., 2011, vol. 6, pp. 275--282.

25. dos-Santos, C.M., and de-Almeida Silva, M., Physiological and biochemical responses of sugarcane to oxidative stress induced by water deficit and paraquat, Acta Physiol. Plant., 2015, vol. 37, pp. 172.

26. Maraschin, S.F., Caspers, M., Potokina, E., Wulfert, F., Graner, A., Spaink, H.P., and Wang, M., cDNA array analysis of stress-induced gene expression in barley androgenesis, Plant., 2006, vol. 127, pp. 535-550.

27. Li, G.W., Zhang, M.H., Cai, W.M., Sun, W.N., and Su, W.A., Characterization of OsPIP2;7 a water channel protein in rice, Plant Cell Physiol., 2008, vol. 49, pp. 1851-1858.

28. Lian, L.L., Yu, X., Lane, D., Sun, W.N., Tang, Z.C., and Su, W.A., Upland rice and lowland rice exhibited different PIP expression under water deficit and ABA treatment, Cell Res., 2006, vol. 16, pp. 651--660.

29. Galmes, J., Pou, A., Alsina, M.M., Tomas, M., Medrano, H., and Flexas, J., Aquaporin expression in response to different water stress intensities and recovery in Richter-110: relationships with ecophysiological status, Planta, 2007, vol. 226, pp. 671--681. 
30. Silva, M.D., Silva, R.L.O., Ferreira-Neto, J.R.C., Guimarães, A.C.R., Veiga, D.T., Chabregas, S.M., Burnquist, W.L., Kahl, G., Benko-Iseppon, A.M., and Kido, E.A., Expression analysis of sugarcane aquaporin genes under water deficit, Nucleic Acids, 2013, doi 10.1155/2013/763945.

\section{Tables}

Table 1: Gene transcripts and their primer sequences

\begin{tabular}{lll}
\hline Target Gene & Forward Primer $\left(\mathbf{5}^{\prime} \mathbf{3}^{\prime} \mathbf{)}\right.$ & Reverse Primer $\left.\mathbf{( 5}^{\prime} \mathbf{3}^{\prime} \mathbf{3}^{\prime}\right)$ \\
\hline ShPIP2; & TCGGTCGCTCTTGTTCAG & GCAGAGAAGCAGCAGGAGAC \\
ShPIP2;5 & CTGACCAAGTGGTCGCTGTA & GTGTCCGTCTGGTGCTTGTA \\
ShPIP2;6 & TGAACGGAGAAGGAGACCAC & CAACACACGCACACCATACA \\
b-tubulin & GGAGGAGTACCCTGACAGAATGA & CAGTATCGGAAACCTTTGGTGAT \\
\hline
\end{tabular}

Table 2. Changes in SOD activity, MDA and $\mathrm{H}_{2} \mathrm{O}_{2}$ content under water deficit $\left(120^{\text {th }}\right.$ and $150^{\text {th }}$ day) in comparison to control condition (120 th day).

\begin{tabular}{lcccccc}
\hline $\begin{array}{l}\text { Sugarcane } \\
\text { genotypes }\end{array}$ & \multicolumn{2}{c}{$\begin{array}{c}\text { SOD } \\
\text { \% Changes }\end{array}$} & \multicolumn{2}{c}{$\begin{array}{c}\text { Lipid Peroxidation (MDA) } \\
\text { Fold changes }\end{array}$} & \multicolumn{2}{c}{$\begin{array}{c}\mathrm{H}_{2} \mathrm{O}_{2} \text { Content } \\
\text { \% Changes }\end{array}$} \\
& $\mathbf{1 3 5}^{\text {th }}$ day & $\mathbf{1 5 0}^{\text {th }}$ day & $\mathbf{1 3 5}^{\text {th }}$ day & $\mathbf{1 5 0}^{\text {th }}$ day & $\mathbf{1 3 5}^{\text {th }}$ day & $\mathbf{1 5 0}^{\text {th }}$ day \\
\hline Co 98014 & 136.9 & 187.7 & 0.4 & 0.7 & 39.4 & 61.4 \\
Co 0118 & 196.5 & 233.5 & 0.6 & 0.7 & 42.3 & 61.2 \\
CoJ 85 & 80.3 & 137.2 & 1.4 & 1.8 & 100.2 & 145.9 \\
Co 89003 & 66.3 & 114.7 & 1.5 & 1.9 & 117.5 & 160.1 \\
\hline
\end{tabular}

\section{Figures}




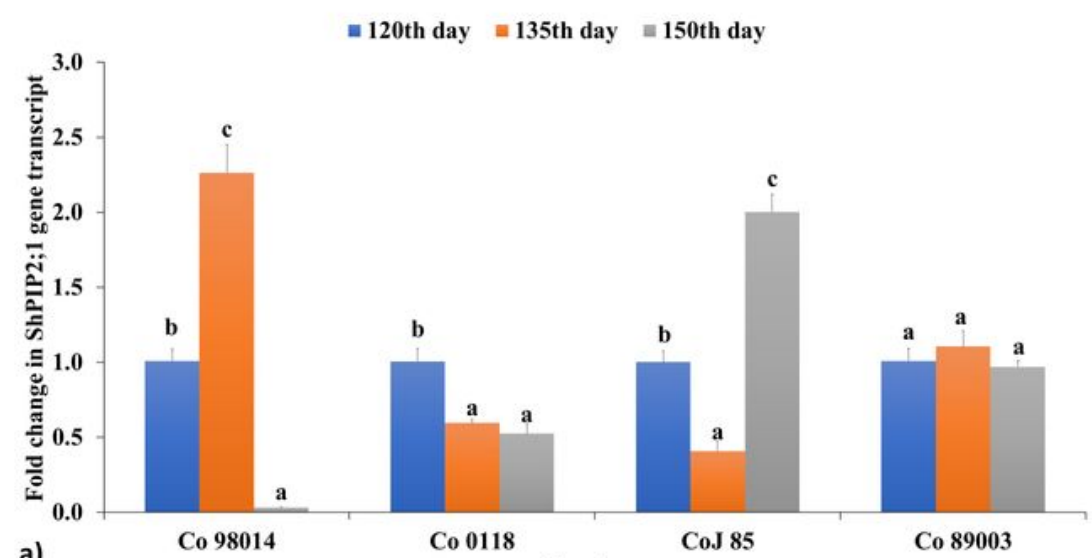

a)

Genotypes

Cos 85

Co 89003
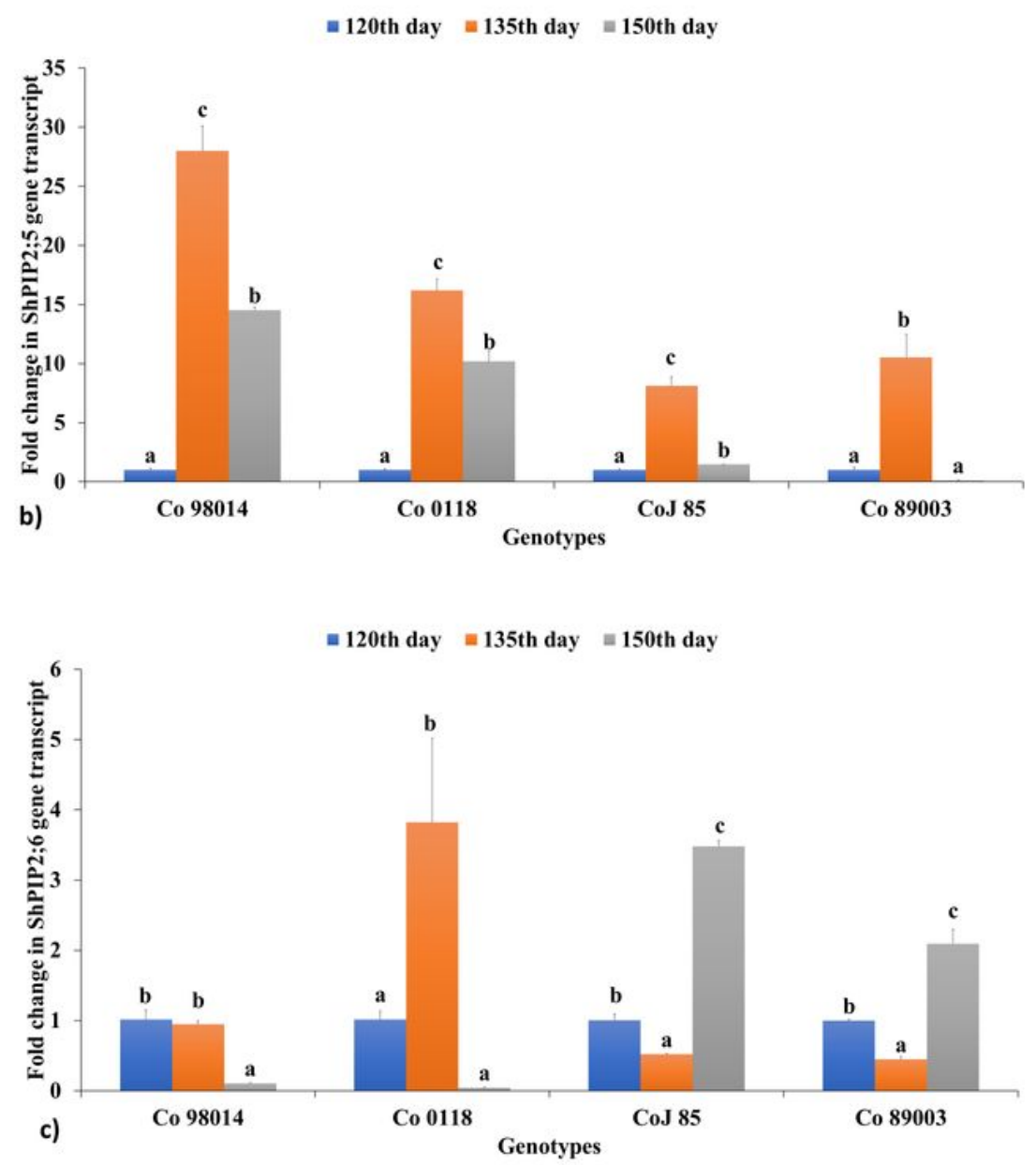

\section{Figure 1}

Observations for Lipid peroxidation (MDA content) a), $\mathrm{H} 2 \mathrm{O} 2$ content b), and Superoxide dismutase (SOD) activity $\mathrm{c}$ ), of sugarcane genotypes during different water deficit conditions. Bars represent mean value and error bars indicated the standard error $( \pm S E)$. The different alphabatical letters upon error bars differ signifianty $(p<0.05)$. 

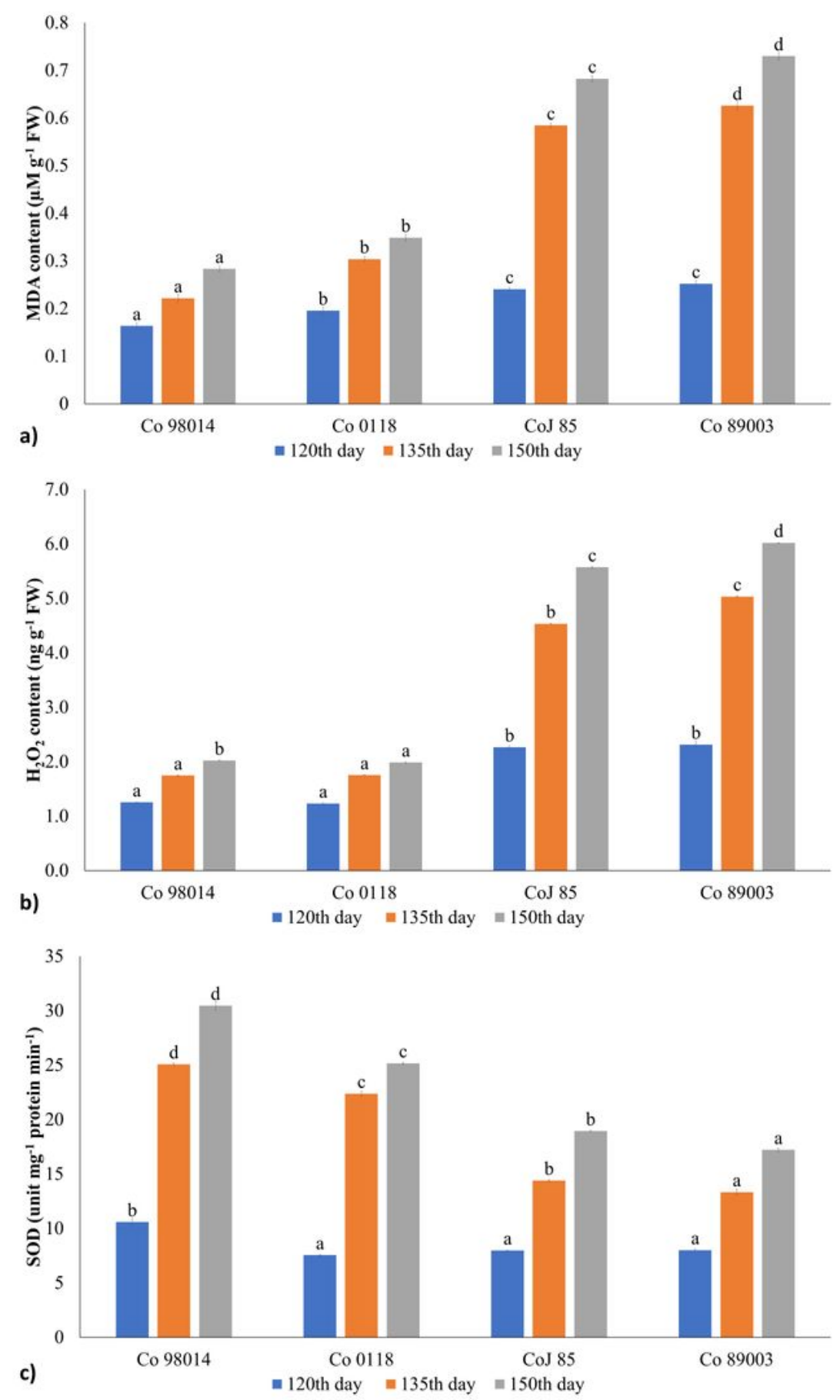

\section{Figure 2}

Fold change in expression pattern of ShPIP2;1 a), ShPIP2;5 b), ShPIP2;6 c), genes in sugarcane genotypes during different water deficit conditions. Bars represent mean transcript value and error bars indicated the standard error ( \pm SE). The different alphabatical letters upon error bars differ signifianty $(p<0.05)$. 